\title{
Soft and Hard Tissue Relations in Facial Asymmetry
}

\author{
Relación de Tejidos Blandos y Duros en Asimetría Facial \\ Sergio Olate, ${ }^{*, * *}$ Mario Cantín ${ }^{* *}$; Mariela Muñoz ${ }^{* * * *}$ \& Bélgica Vásquez ${ }^{* * * * *}$
}

OLATE, S.; CANTÍN, M.; MUÑOZ, M. \& VÁSQUEZ, B. Soft and hard tissue relations in facial asymmetry. Int. J. Morphol., 34(3):1058-1062, 2016.

\begin{abstract}
SUMMARY: The aim of this study was to determine the relations between hard and soft tissues in subjects with facial asymmetry. Included were subjects aged between 15 and 35 years who presented a chin deviation greater than $5 \mathrm{~mm}$ from the midline and a unilateral posterior crossbite. Cone beam computed tomography was used to determine the measurements, positioning them on the three spatial planes; then, 5 bilateral bone points were selected on the coronal image, and parallel measurements were taken to determine the range between the bone point and the most lateral soft tissue point. The statistical analysis was done using the Shapiro-Wilk test, presenting normality in the sample distribution and Levene's test, considering a value of $p<0.05$ to obtain significant differences. 20 subjects were included with an average age of 23 years, observing that there were differences in the soft tissue distance in relation to the mandibular condylar head; in other measurements, there were no significant differences, although tendencies of greater or less soft tissue width in relation to the mandibular sector of the asymmetry were observed. It may be concluded that there are limited differences in soft tissue width in subjects with facial asymmetry; the low sample number and the selection of new points may have influenced the results.
\end{abstract}

KEY WORDS: Facial asymmetry; Facial analysis; Soft tissues.

\section{INTRODUCTION}

Body and facial symmetry is determined by many factors involved in human growth and development. In general terms, there are proportions, angles and linear measurements that govern relations between the different structures that compose the face. The esthetic considerations in the facial context are varied, but under certain conditions they can be similar in the observation of various people; for example, Naini et al. (2012) defined chin prognathism at 6 $\mathrm{mm}$ and chin retrognathism at $10 \mathrm{~mm}$ and associated this with the need for surgical modification for all those involved in the study, showing that certain parameters are crosssectional in today's society.

Issues regarding normality and beauty provide objective and measurable elements in that the perception of normality determines self-confidence, safety and identification (Springer et al., 2012), where facial asymmetry definitely makes this impossible. Mess et al. (2013) established certain parameters of facial normality and esthetics in men and women, indicating that the manner of protrusion of the middle and lower third would be enough to determine a better esthetic result. When this is very protruded or retruded, it is seen as having a low esthetic value; this condition is viewed from the side and does not have the same impact when viewed from the front, where facial symmetry plays an even more important role.

Evaluations of the facial esthetic have identified that soft tissue relations between different structures can be involved in the perception of attraction and beauty. The important factors in this analysis are most likely the nasofrontal and nasolabial angles, the vertical dimension of the lower third and protrusion of the upper lip in relation to the lower lip (Khosravanifard et al., 2013). The specific considerations in the lower third are related to the chin position and mandibular angle; the mandibular angle in men has requirements oriented toward the intergonial and interzygion distance, where the necessary angle would be $130^{\circ}$, enabling a suitable separation from the neck (Mommaerts, 2016).

In subjects with facial deformity, the shape of the face maintains a morphology that also involves functional alterations. Particularly in the case of facial asymmetries, there

\footnotetext{
* Division of Oral and Maxillofacial Surgery, Universidad de La Frontera, Chile.

** CEMyQ, Universidad de La Frontera, Chile.

**** Center for Biomedical Research, Universidad Autónoma de Chile, Chile.

***** Universidad de Tarapacá, Chile.
} 
is an adaptation of different body structures to the asymmetry which enables muscles, ligaments and bone structure to adjust in order to function on an abnormal morphological base (Muñoz et al., 2014; Goulart et al., 2015).

Unlike symmetrical sagittal deformities, in facial asymmetry there is a different angle between the direction of the mandibular ramus and the midline on the frontal plane, which causes the lower third of the face to shift laterally, which clinically manifests in deviation of the chin from the midline together with occlusal alterations. In some cases, there is vertical alteration in the position of the maxilla, caused by the progressive deviation of the mandible, which causes an asymmetry in the middle third of the face (Olate et al., 2013).

The bone morphology in subjects with facial asymmetry is partially defined, with patterns that can be related to the shape of the mandibular condyle and the degree of facial asymmetry, making it possible for treatments to be indicated (Olate et al., 2014). The soft tissue morphology and its relation to bone tissues, however, has not been fully defined. It is possible to suppose that facial asymmetry of the lower third can generate asymmetry in the shape and direction of muscles, which entails important determinants in corrective surgical procedures.

The aim of this study was to determine the difference in soft tissue width in subjects with facial asymmetry at the level of the lower third of the face.

\section{MATERIAL AND METHOD}

Subjects of both sexes with cross-sectional facial asymmetry aged between 15 and 35 years were included. Inclusion criteria used were: subjects with chin deviation greater than $5 \mathrm{~mm}$ from the midline, presence of unilateral posterior crossbite and deviation of the interincisal midline. Subjects with other facial deformities, facial malformations, facial asymmetry associated with unilateral posterior open bite or a history of trauma and facial surgeries were excluded.

All the subjects underwent a comprehensive diagnosis using cone beam compute tomography (CBCT). This was obtained with the patients in the dental position of maximum intercuspidation; the head was positioned on the Frankfort Plane, keeping the sagittal plane parallel to the floor. The images were obtained on a Vatech PaxZenith CBCT unit (Korea 2011), using $90 \mathrm{kV}$ and $120 \mathrm{~mA}$; FOV 8x6 cm, voxel size $0.12 \mathrm{~mm}$. Cuts were made with sections at $1 \mathrm{~mm}$ intervals and evaluated using the respective software.
After establishing cranial positions based on the standard angulation of the axial and lateral positions of the tomography, the measurements were determined on traces made on the images selected by the software using a 1:1 scale. The coronal view was used, obtaining distances between the bone points and the most lateral point of soft tissues; all measurements were taken with lines parallel to each other. The soft bone tissue points selected were bilateral including:

a. Lateral condyle: most lateral point of the condylar head.

b. Coronoid process: most lateral and superior point of the coronoid process.

c. Zygomatic arch point: central and lateral point of the zygomatic arch.

d. Second posterior molar: lateral cervical distal point of the second inferior molar.

e. Mandibular body: central point of the vertical distance of the mandibular body obtained at the same cut of the second molar.

f. Mental foramen: superior and lower point of the mental foramen.

To compare the right and left side, it was defined that the side that presented the deviation (ipsilaterally to the chin deviation) would be called "elongated" and the contralateral side would be called "shortened" (Fig. 1).

Each measurement was taken by the same operator and repeated twice at a 6-day interval. The Student's ttest was used for each measurement to evaluate the differences between the right and left sectors; the ShapiroWilk test showed normality in the sample distribution, and Levene's test identified homogeneity of the variance. The error was assessed by the correlation coefficient, obtaining a value of 0.99 with a $\mathrm{p}$ value of 0.001 . The value $\mathrm{p}<0.05$ was considered to establish significant differences.

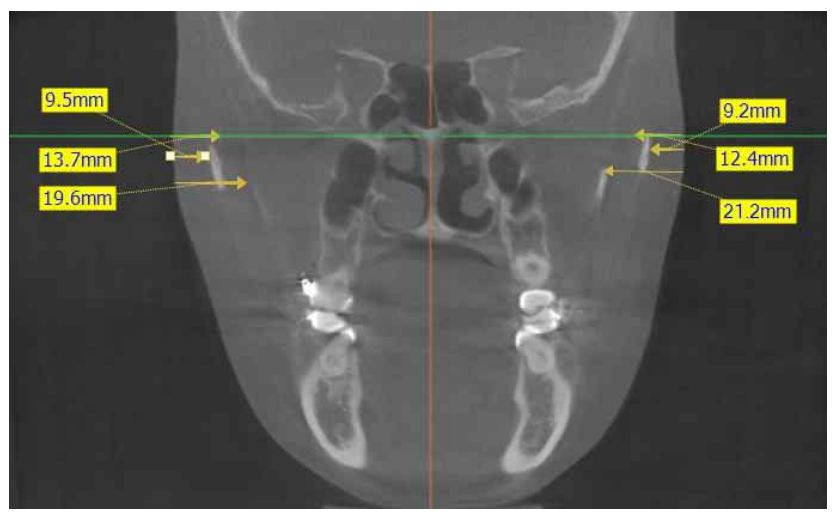

Fig. 1. Measurement obtained in the coronal view of CBCT. 


\section{RESULTS}

Twenty subjects were included in the study, establishing the difference of soft tissue position between the two sides in subjects with facial asymmetry. The average age of the subjects was 23.67 years, with 13 subjects being female and 7 male. The facial asymmetry presented predominantly towards the left in 12 subjects, whereas 8 had a deviation to the right.

The zygomatic arch region defined the middle third of the face, based on craniofacial fixed points; in these, differences of just $0.1 \mathrm{~mm}$ were obtained, in the absence of significant differences, indicating that there is no difference between these sectors in cases of facial asymmetry ( $p>0.05)$. On the other hand, differences were observed in different mandibular zones, demonstrating that the mandibular zone exhibits alterations or modifications in its relation with soft tissues (Table I).

Differences less than $2 \mathrm{~mm}$ were observed between the right and left side. It was observed that the hemifacial sector called "elongated" (area that generates facial asymmetry by moving the chin towards the contralateral side) presented a shorter distance between hard and soft tissues in the region of the condylar process and coronoid process than the "shortened" sector. This condition changes when it is analyzed at the level of the second molar, mandibular body and mental foramen, where the distance between hard and soft tissues is greater in the "elongated" sector. The studies showed that only the condylar head zone presented significant differences $(\mathrm{p}=$ 0.021 ). None of the other measurements taken showed any significant differences.

\section{DISCUSSION}

Facial asymmetry has been studied in different conditions using a variety of methods (Nord et al., 2015).
3D studies have been used recently in analysis, diagnosis and surgical planning; without a doubt it represents a real option where costs, learning curve and working time have influenced the slow incorporation into daily practice (Olate et al., 2016). 2D studies have also been incorporated into the analysis of facial asymmetry, integrating soft tissue analysis and the analysis of $\mathrm{x}$-ray images (Olate et al., 2015).

One of the most significant difficulties in the relation between hard and soft tissues lies in the threedimensionality of the face and its value to facial dynamics. Nevertheless, a starting point in this analysis is the static definition of some sectors involved in facial asymmetry. Berlin et al. (2014), studying methods of reference in facial asymmetries, identified that obtaining angles and lines based on few points of measurement would be an obstacle in the definition of facial asymmetry. In 3D models, the mirror image can be an alternative, being confirmed by Ozsoy (2016). Berssenbrügge et al. (2014) determined that the study of soft tissues in facial asymmetry yields similar results when comparing $2 \mathrm{D}$ and $3 \mathrm{D}$ studies; they determined that 5 points of measurement in $2 \mathrm{D}$ studies is the minimum needed to make comparisons, considering that 3D measurement systems present nearly 10,000 points for use in comparisons.

Options in the study of the face asymmetry have been proposed recently by Verhoeven et al. (2016), who compared the content analysis in marks and points with lines and angles using surface-based records; they determined that there was no difference between the two, which allows both analyses in the diagnosis. The surface analysis consists of multiple points, with $1 \mathrm{~mm}$ between them, which would provide for greater accuracy in these analyses. In all these studies, the basic determinant is the analysis of asymmetry with a poorly assessed relation between hard and soft tissue. Any correction of the asymmetric deformity must respond to the regulation of this relation, since the view of the soft tissue is really what the facial esthetic analysis focuses on. Our results indicate that at the level of the zygomatic arch

Table I. Measurements obtained in 20 subjects with facial asymmetry comparing the "elongated" sector (side that generates chin deviation) and the "shortened" sector (side to which the chin asymmetry is directed).

\begin{tabular}{|c|c|c|c|c|c|c|c|c|c|c|c|c|}
\hline \multirow{2}{*}{$\begin{array}{c}\text { Mandibular } \\
\text { zone }\end{array}$} & \multicolumn{2}{|c|}{ Arch } & \multicolumn{2}{|c|}{ Condylar head } & \multicolumn{2}{|c|}{$\begin{array}{l}\text { Coronoid } \\
\text { process }\end{array}$} & \multicolumn{2}{|c|}{$\begin{array}{c}\text { Lower second } \\
\text { molar }\end{array}$} & \multicolumn{2}{|c|}{$\begin{array}{c}\text { Mandibular } \\
\text { body }\end{array}$} & \multicolumn{2}{|c|}{ Mental foramen } \\
\hline & $\mathrm{x}$ & $\mathrm{sd}$ & $\mathrm{x}$ & $\mathrm{sd}$ & $\mathrm{x}$ & $\mathrm{sd}$ & $\mathrm{x}$ & $\mathrm{sd}$ & $\mathrm{x}$ & $\mathrm{sd}$ & $\mathrm{x}$ & $\mathrm{sd}$ \\
\hline Elongated & 8.8 & 1.12 & 12.31 & 1.71 & 20.89 & 1.87 & 27.85 & 2.33 & 15.85 & 2.45 & 20.24 & 3.01 \\
\hline Shortened & 9 & 1.37 & 14.11 & 2.47 & 21.9 & 2.18 & 26.36 & 3.08 & 15.22 & 1.87 & 18.39 & 2.86 \\
\hline Difference & 0.1 & - & 1.8 & - & 1.01 & - & 1.49 & - & 0.63 & - & 1.85 & - \\
\hline
\end{tabular}


there is no difference between the two sectors, but in the condylar sector significant differences are seen; it is likely that the low sample number affects the absence of significant differences in the sector of mandibular body.

Techniques such as the increase in contour and mandibular angle with alloplastic systems have been proposed (Semergidis et al., 1996), but they have failed in ascertaining the point at which, in which sector and in how many millimeters differences can be observed in the results of unilateral increase. The treatments provided to recover facial symmetry require knowledge of the presence of soft tissues and depth with the esthetic components. Fang et al. (2016) determined that the mandibular contour in subjects with facial asymmetry is related to morphological modifications in the basal area, so that the mandibular contour can also influence its relation to the soft tissues. This observation may also explain the differences in residual facial asymmetries, where the surgical correction is not aimed at improving the contour morphology and seeks only to position the dentoalveolar region symmetrically.

With the limitations of this study, it is possible to conclude that there are limited differences in the relation of soft and hard tissues between the right and left side in subjects with facial asymmetry; studies with a larger sample and with other points of measurement are needed to establish therapeutic approaches.

OLATE, S.; CANTÍN, M.; MUÑOZ, M. \& VÁSQUEZ, B. Relación de tejidos duros y blandos en asimetría facial. Int. J. Morphol. 34(3):1058-1062, 2016.

RESUMEN: El objetivo de esta investigación fue determinar la relación entre tejidos duros y blandos en sujetos con asimetría facial. Se incluyeron sujetos de entre 15 y 35 años que presentaban desvío de mentón mayor a 5 mm desde la línea mediana y mordida cruzada posterior unilateral; se realizó una tomografía computadorizada de haz cónico para determinar las mediciones posicionándola en los tres planos espaciales; luego se realizó la selección de 5 puntos óseos bilaterales, en la imagen coronal y se realizaron mediciones paralelas para determinar la distancia entre los puntos óseo y de tejido blando más lateral; para el análisis estadístico se utilizó la prueba Shapiro-Wilk presentando normalidad en la distribución de la muestra y la prueba de Levene considerando un valor de $\mathrm{p}<0,05$ para obtener diferencias significativas. Veinte sujetos fueron incluidos con una edad promedio de 23 años y se observó que existían diferencias en la distancia de tejidos blandos en relación a la cabeza de cóndilo mandibular; en otras mediciones no se presentaron diferencias significativas aunque se observaron tendencias de mayor o menor ancho de tejidos blandos en relación al sector mandibular de la asimetría. Se puede concluir que existen limitadas diferencias en ancho de tejidos blandos en sujetos con asimetría facial; el bajo número muestral y la selección de nuevos puntos pueden influir en los resultados observados.

PALABRAS ClAVE: Asimetría facial; Análisis facial; Tejidos blandos.

\section{REFERENCES}

Berlin, N. F.; Berssenbrügge, P.; Runte, C.; Wermker, K.; Jung, S.; Kleinheinz, J. \& Dirksen, D. Quantification of facial asymmetry by $2 \mathrm{D}$ anslysis - A comparison of recent approaches. J. Craniomaxillofac. Surg., 42:265-71, 2014.

Berssenbrügge, P.; Berlin, N. F.; Kebeck, G.; Runte, C.; Jung, S.; Kleinheinz, J. \& Dirksen, D. 2D and 3D analysis methods of facial asymmetry in comparison. J. Craniomaxillofac. Surg., e327-34, 2014.

Fang, J. J.; Tu, Y. H.; Wong, T. Y.; Liu, J. K.; Zhang, Y. K.; Leong, I. F. \& Chen, K. C. Evaluation of mandibular contour in patients with significant facial asymmetry. Int. J. Oral Maxillofac. Surg., 45:922-31, 2016.

Goulart, D. R.; Muñoz, P.; Olate, S.; de Moraes, M. \& Fariña, R. No differences in morphological characteristics between hyperplastic condyle and class III condyle. Int. J. Oral Maxillofac. Surg., 44:1281-6, 2015.
Khosravanifard, B.; Rakhshan, V. \& Raeesi, E. Factors influencing attractiveness of soft tissue profile. Oral Surg. Oral Med. Oral pathol. Oral Radiol., 115:29-37, 2013.

Mommaerts, M.Y. The ideal male jaw angle - An internet survey. J. Craniomaxillofac. Surg., 44:381-91, 2016.

Mees, S.; Jiménez Bellinga, R.; Mommaerts, M. Y. \& De Pauw, G. A. M. Preference of AP position of the straight caucasian facial profile. J. Craniomaxillofac. Surg., 755-63, 2013.

Muñoz, M.; Goulart, D. R.; Olate, S.; de Moraes, M.; Navarro, P. \& Fariña, R. Analysis of the condyle, articular fossa, and mandibular ramus in subjects with active condylar hiperplasia. Int. J. Morphol., 32(3):1064-8, 2014.

Naini, F. B.; Donaldson, A. N. A.; McDonald, F. \& Cobourne, M.T. Assessing the influence of chin prominence on perceived attractiveness in the orthognathic patient, clinician 
and layperson. Int. J. Oral Maxillofac. Surg., 41:839-46, 2012.

Nord, F.; Ferjencik, R.; Seifert, B.; Lanzer, M.; Gander, T.; Matthews, F.; Rücker, M. \& Lübbers, H. T. The 3dMD photogrammetric photo system in cranio-maxillofacial surgery: Validation of interexaminer variations and perceptions. $J$. Craniomaxillofac. Surg., 43(9):1798-803, 2015.

Olate, S.; Netto, H. D.; Rodriguez-Chessa, J.; Alister, J. P.; ALbergaria-barbosa, J. R. \& de Moraes, M. Mandible condylar hiperplasia: a review of diagnosis and treatment protocol. Int. J. Clin. Exp. Med., 6:727-37, 2013.

Olate, S.; Unibazo, A.; Almeida, A. \& de Moraes, M. Mandibular condylectomy revisited: technical notes concerning the use of an ultrasonic system. J. Oral Maxillofac. Surg., 72:481-4, 2014.

Olate, S.; Cantín, M.; Vásquez, B.; Muñoz, M. \& de Moraes, M. 2D Photography in facial asymmetry diagnosis. Int. J. Morphol., 33(4):1483-6, 2015.

Olate, S.; Zaror, C.; Blythe, J. N. \& Mommaerts, M.Y. A systematic review of soft-to-hard tissue ratios in orthognathic surgery. Part III: Double jaw surgery procedures. J. Craniomaxillofac. Surg., doi: 10.1016/j.jcms.2016.08.016, 2016.

Ozsoy, U. Comparison of different claculation methods used to analyze facial soft tissue asymmetry: Global and partial 3-Dimensional quantitative evaluation of healthy subjects. J. Oral Maxillofac. Surg., 74:1847.e1-9, 2016.

Semergidis, T.; Migliore, S. \& Sotereanos, G. Alloplastic augmentation of mandibular angle. J. Oral Maxillofac. Surg., 54:1417-23, 1996

Springer, I. N.; Wiltfang, J.; Kowalski, J. T.; Russo, P. A. J.; Schulze, M.; Becker, S. \& Wolfart, S. Mirror, mirros on the Wall...: Self-perception of facial beauty versus judgement by others. J. Craniomaxillofac. Surg., 40:773-6, 2012.

Verhoeven, T.; Xi, T.; Schreurs, R.; Bergé, S. \& Maal, T. Quantification of facial asymmetry: A comparative study of landmark-based and surface-based registration. $J$. Craniomaxillofac. Surg., http://dx.doi.org/10.1016/ j.jcms.2016.07.017, 2016.

\author{
Correspondence to: \\ Prof. Sergio Olate \\ División de Cirugía Oral y Maxilofacial \\ Claro Solar 115 Oficina 414-A \\ Temuco \\ CHILE
}

Email: sergio.olate@ufrontera.cl

Received: 04-05-2016

Accepted: 19-07-2016 